\title{
Analysis of the scientific production of olive products. I - Table olives
}

\author{
By Rosa de la Viesca, Elena Fernández and Javier Salvador* \\ Centro de Información y Documentación Científica (CINDOC) \\ Consejo Superior de Investigaciones Científicas (CSIC)
}

\begin{abstract}
RESUMEN
Análisis de la producción científica acerca de los productos del olivo. I - Aceitunas de mesa.

Este artículo presenta un panorama de la producción científica en el área de las aceitunas de mesa durante el periodo 2000-2005. Utilizando indicadores bibliométricos básicos, se ha estudiado la productividad de los autores, los temas más comúnmente tratados, las fuentes de información y los grupos de autores. Además, se analizan las colaboraciones realizadas entre diferentes grupos de investigación. Por último, se incluyen los indicadores de impacto de las revistas más prestigiosas en el sector.
\end{abstract}

PALABRAS-CLAVE: Aceitunas de mesas - Análisis bibliométrico - Producción científica.

\section{SUMMARY}

Analysis of the scientific production of olive products. I - Table olives

This article contains an overview of the scientific production in the area of table olives during the period 20002005. Author's productivity, most relevant topics, sources of information and groups of authors are analysed using basic bibliometric indicators. Also, contributions and collaborations among groups of authors are studied. Finally, this work includes impact indicators from the most important journals on this topic.

KEY-WORDS: Bibliometric analysis - Scientific production - Table olives.

\section{INTRODUCTION}

The main objective of this work is to give an overview of the scientific production (published as articles in scientific journals) in the area of the food products of olive trees. The purpose is to know the main research groups currently working, detect the research organizations involved, find the topics now being researched and the journals most widely used in publishing as well as the countries where the research is carried out. This article will contribute to the technological watch developed under the broader European Union VI Frame Program project (SSA number FOOD-CP-2004-
505524) aiming to support the European SMEs in this food production area. ${ }^{1}$

\section{METHODOLOGY}

References have been obtained from the database of the Science Citation Index, named Scisearch ${ }^{2}$, created by the Institute of Scientific Information. This ISI database was chosen among others more specific, such as the FSTA ${ }^{3}$ (Food Science and Technology Abstracts) as it is the only one to register every author signing an article. This feature allows to detect coauthorship and institutional collaboration. Both databases were consulted in the Web of Knowledge created by the Thomson Corporation.

The study has two different parts: one scientific production on table olives and the other on olive oil.

The methodology used is merely a bibliometric analysis, constructed upon publication data, which enables us to obtain an interesting overview of the state of scientific research in the specific field of table olives.

From the references obtained, in May 2005, a set of indicators has been extracted, which give a general picture of the situation of research in these topics during the period 2000-2005. This information is most probably of high interest for the innovative SMEs.

The indicators used in this study are those of production, dissemination or distribution and impact ${ }^{4}$. We give the following definition of them:

\section{Production}

- Productivity: The Lotka's law describes the publication by authors in a given field. It states that the number of authors making $n$ contributions is about $1 / \mathrm{n}^{\mathrm{a}}$ of those making one contribution, where a is often nearly 2 .

- Cooperation: The average number of authors by publication

- Citations: The average number of citation received by article published

Dissemination or distribution

- Core journals. The Bradford's law states that journals in a field can be divided into three 
parts, each with about one-third of all articles: 1) a core of a few journals, 2) a second area , with more journals, and, 3) a third zone, with the bulk of journals. The number of journals increases exponentially in the three areas Impact

- They measure the Visibility of the publications

\section{RESULTS}

a) Production. The total number of articles published during the five year period 20002004 on this subject of table olives and in journals covered by the Science Citation Index is 101. It is a very low number in comparison with the publications in the same period on olive oil (1,363 items). See in Figure 1 how they have been distributed over the years since 1980 . It was only in the last period 2000-2005 when the production has really increased.

b) Productivity . The number of authors of the 101 articles under study is 220. Figure 2 shows their distribution according to the Lotka's law. Only one author has a productivity level higher than 1 , as he is the author in over 10 publications, 12.6 authors

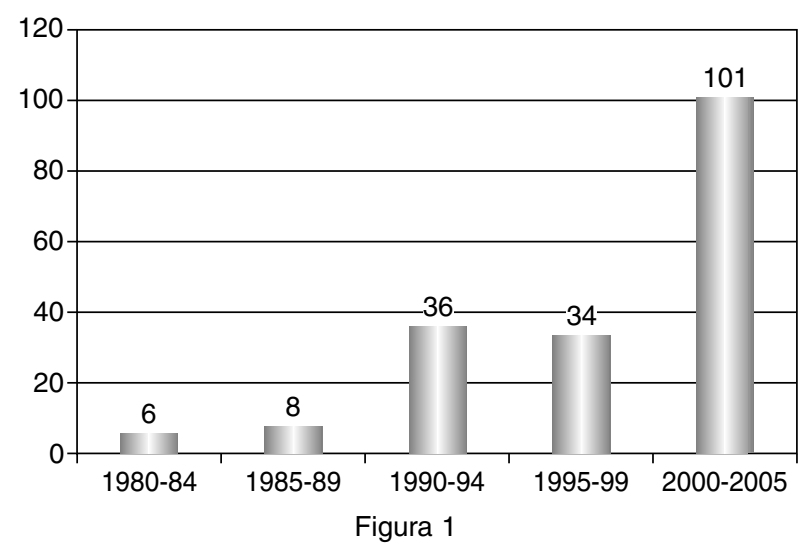

Evolution over years of the number of articles on table olives in the Scisearch: $1980-2005$. In the $x$ axe, number of authors; in the $y$ axe, number of articles published.



Author productivity. In the $x$ axe, number of authors. In the $y$ axe, productivity level. are publishing 2 or more articles and 155 have published only one article in the five years considered.

The collaboration index is increasing with time as the interdisciplinary aspect, in addition the productivity, mobility and visibility of authors have are positive factors ${ }^{5,6}$

c) Research subject. The subject distribution is shown in Figure 3, according to the $\mathrm{SCl}$ classification. $63 \%$ of the papers belong to Food Science and Techonology followed by Applied Chemistry (35\%). The addition of all the percentages is greater than $100 \%$, as some articles are classified in more than one subject area.

d) Research groups. The detection of the different groups working on table olives, we think, will be of great interest to the readers of this article. The groups are based on the study of the coauthorships. This information on where to find the specialists working on a specific subjects has the potential to facilitate the approach of SMEs to the research world, in search of problem solving.

The 5 groups detected are:

\section{Group 1}

Organization: Departamento de Biotecnología de Alimentos del Instituto de la Grasa. CSIC.

Total number of publications: 14

Disciplines under study

- Food Science \& Technology $(77,5 \%)$

- Chemistry, Applied (37,5\%)

- Biotechnology \& Applied Microbiology $(37,48 \%)$

- Agriculture (26\%)

- Engineering, Chemical $(24,2 \%)$

- Microbiology (18,3\%),

- Nutrition and Dietetics (6,7\%)

- Biochemistry \&Molecular biology (3,34\%)

- Biology $(2,5)$

This group is working mainly on the study and optimisation of the fermentation process to improve the quality of table olives. They use different analytical techniques, commonly used in food characterization, such as chromatographic, spectrographic, etc. They are working in two areas Food Science \& Technology and in Biotechnology.



Figura 3

Subject distribution. 


Collaboration with other institutions or
enterprises:
- Institute of Food Research, belonging to the
Biotechnology \& Biological Sciences Research
Council, United Kingdom.
- Agro Sevilla Aceitunas, Spain (7\%)

\section{Group 2}

Organization: Departamento de Ingeniería Química y Energética, Extremadura University

Country: Spain

Total number of publications: 6

Disciplines under study

- Environmental Sciences $(66,7 \%)$

- Engineering, Chemical $(33,3 \%)$

- Engineering Civil (33,3\%)

- Engineering, Environmental (33,3\%)

- Biotechnology \& Applied Microbiology (16,7\%)

- Toxicology (16,7\%)

Their main research interest lies in the regeneration of the waste water produced in the fermentation process of table olives, in the bleaches used and the environmental impact that this food industry produces. (Environmental Engineering).

Collaboration with other institutions or enterprises:

No collaboration in the publications detected

\section{Group 3}

Organization: Calabria University

Country: Italy

Total number of publications: 8

Disciplines under study

- Food Science \& Technology (87,5\%)

- Chemistry, Applied (25\%)

- Agriculture (12,5\%)

- Chemistry, Analytical (12,5\%)

- Nutrition and Dietetics (12,5\%)

The main activity of this group is the characterization of table olives using instrumental techniques. Basically they are studying the phenolic compounds due to their antioxidant properties, preventive effects on cancer and cardiovascular diseases. (Food Science \& Technology)

Collaboration with other institutions or enterprises:

- La Sapienza University, Rome, Italy (37,5\%)

\section{Group 4}

Organización: National Agricultural Research Foundation - NAGREF

Country: Greece

Total number of publications: 8

\section{Disciplines under study}

- Food Science \& Technology $(87,5 \%)$

- Chemistry, Applied (25\%)

- Agriculture (12,5\%)

- Chemistry, Analytical (12,5\%)

- Nutrition and Dietetics (12,5\%)

Their central objective of this group is the study of the fermentation processes of table olives.

Collaboration with other institutions or enterprises:

- Food Research Norwich, United Kingdom (12,5\%)

- Dept. of Food Science and Technology , Agricultural University of Athens, Greece (50\%)

- Institute of Technology of Agricultural Products, NAGREF, Atenas , Greece (12,5\%)

\section{Group 5}

Organization: Dept. of Food Science and Technology, Agricultural University of Athens

Country: Greece

Total number of publications: 7

Disciplines under study

- Microbiology $(85,7 \%)$

- Biotechnology \&Applied Microbiology $(71,4 \%)$

- Food Science \& Technology (4\%)

Collaboration with other institutions or enterprises:

- Institute of Food Reserach, Reino Unido (57\%)

- National Agricultural Research Foundation (NAGREF), Grecia (42,9\%)

e) Country distribution: the country with a higher production in this topic of table olives is Spain (51\%), followed by Italy (22\%), Greece (17\%) and Portugal (8\%). These results are expected as they are in correlation with the production of this food in the countries mentioned.

f) Research group collaboration. The two Spanish groups detected, numbers 1 and 2 work independently as their subject areas are different. Two collaborations of the Instituto de la Grasa from the Spanish National Research Council have been identified: one with Institute of Food Research, United Kingdom and the other with the enterprise Agro Sevilla Aceitunas, Spain. In Italy only one group belonging to the Calabria University is active in the field, they collaborate with the Sapienza University in Rome. Finally, in Greece two groups have been detected.

They are the most collaborative groups of the 5 observed. They collaborate among their own organizations and with the Food Research Norwich in the United Kingdom.

g) Scientific journals. A total of 101 documents dealing with table olives were published in 46 journals covered by Scisearch since 2000 . Approximately half of the documents $(47,5 \%)$ 
Table 1

Bradford distribution in journals in the core.

\begin{tabular}{lccc}
\hline \multicolumn{1}{c}{ Journal titles } & $\begin{array}{c}\text { Number } \\
\text { of } \\
\text { articles }\end{array}$ & $\begin{array}{c}\text { Cumulative } \\
\text { number } \\
\text { of articles }\end{array}$ & $\begin{array}{c}\text { Cumulative } \\
\%\end{array}$ \\
\hline Journal of Agricultural and Food Chemistry & 10 & 10 & 9,90 \\
Grasas y aceites & 9 & 19 & 18,80 \\
Journal of the Science of Food and Agriculture & 8 & 27 & 26,72 \\
Journal of Food Protection & 7 & 34 & 33,65 \\
Food Chemistry & 6 & 40 & 39,58 \\
Food Microbiology & 4 & 44 & 43,54 \\
Process biochemistry & 4 & 48 & 47,50 \\
\hline
\end{tabular}

Table 2

Impact indicators.

\begin{tabular}{lccccc}
\hline Journal Title & $\begin{array}{c}\text { Total number } \\
\text { of citations 2003 }\end{array}$ & $\begin{array}{c}\text { Impact } \\
\text { Factor }\end{array}$ & $\begin{array}{c}\text { Immediacy } \\
\text { Index }\end{array}$ & $\begin{array}{c}\text { Number of } \\
\text { articles 2003 }\end{array}$ & $\begin{array}{c}\text { Cited } \\
\text { Half-life }\end{array}$ \\
\hline J.Agr. food. Chem. & 23739 & 2.102 & 0.304 & 1285 & 5.9 \\
Grasas y Aceites & 332 & 0.351 & 0.040 & 25 & 9.5 \\
J. Sci Food Agr. & 6031 & 0.978 & 0.096 & 228 & $>10.0$ \\
J. Food Protect & 7164 & 2.154 & 0.254 & 350 & 6.2 \\
Food Chem. & 4094 & 1.204 & 0.193 & 305 & 5.9 \\
Food Microbiol. & 1170 & 1.049 & 0.087 & 92 & 6.5 \\
Process Biochem. & 1829 & 1.073 & 0.081 & 173 & 4.8 \\
\hline
\end{tabular}

were published in 7 journals and the remaining in 39 different titles. Table 1 shows the list of core journals following the Bradford distribution

h) Impact indicators. They measure the visibility of the scientific published production and therefore the visibility of authors and organizations. This is done by studying the citations that articles receive. The Institute of Scientific Information prepares the Journal Citation Reports and in Table 2 the main indicators of the journals that are part of the core journal in olive oil are listed.

\section{CONCLUSIONS}

1. Productivity: The ranking of productivity by country is Spain, Italy and Greece in a clear correlation with the main producing countries of table olives.

2. Research subject: The main disciplines in which the researchers are working are: Food Science and Technology; Biotechnology and Applied Microbiology; Agriculture; and Environmental Engineering

3. Journals: The results of the research are published in a core of 7 journals (one of them Spanish).

4. Groups: Two groups are active in Spain, one working in Food Technology and the other one in Environmental Engineering. Their research is quite independent and therefore the collaboration very occasional.

In Italy a group in the Calabria University collaborates with another University, which is La Sapienza in Rome.
In Greece two are the groups detected, which have a higher degree of collaboration than the other groups mentioned before. They are specialists in Biotechnology and Applied Microbiology and in Food Technology

5. Industrial sector: The presence of the industry in research activity is nearly nonexisting and this constitutes a major concern which has to be tackled in the near future.

6. Co-authorship: The average value of authors per article is relatively high $(3,84)$. Only 6 of the documents considered have a single author and a $36 \%$ were signed by 4 authors.

\section{BIBLIOGRAPHY}

Setting-up a network of Technology Dissemination Centres to optimise SMEs in the olive and olive oil sector, TDCOLIVE. <http://www.tdcolive.org>

ISI Web of Knowledge. <http.//isi02.isiknowledge.com>

ISI Web of Knowledge. <http.//isi02.isiknowledge.com>

López-Piñero J.M., Terrada M.L. 1992. Los Indicadores de producción, circulación, dispersión, consumo de la información y repercusión. Medicina Clínica 98, 142-148.

Arunachalam S., Jinandra Doss M. 2000. Science in a small country at a time of globalization: domestic and internacional collaboration in new biology research in Israel. Journal of Information Science 26, 39-49.

Gläncel W., Shubert A., Czerwon, H.J. 1999. A bibliometric analysis of International Scientific Cooperation of the European Union (1985-1995). Scientometrics 45, 185-202. 